\title{
Identification of a New Locus in the Escherichia coli Cotransduction Gap that Represents a New Genetic Component of the L-Asparagine Utilization System
}

\author{
By ROBERT H. CHESNEY,* PAUL SOLLITTI AND DONNA R. VICKERY \\ Department of Zoology and Physiology, Rutgers University, Newark, NJ 07102, USA
}

(Received 18 January 1985)

\begin{abstract}
A temperature-sensitive Escherichia coli mutant defective for the ability to utilize L-asparagine as a sole nitrogen source was isolated after $N$-methyl- $N^{\prime}$-nitro- $N$-nitrosoguanidine mutagenesis. The mutation (asu) produces two distinct phenotypic effects. (1) Mutant strains grow poorly at high temperature on minimal plates containing asparagine as the sole nitrogen source; this effect is greatly exacerbated by the presence of methionine. (2) Mutant strains utilize Lasparagine as a nitrogen source three to four times more efficiently at permissive temperatures than the wild-type strains. The mutation maps at $32.4 \mathrm{~min}$ on the $E$. coli chromosome, within the $E$. coli cotransduction gap. Mutant strains produce normal amounts of thermo-stable Lasparaginase I activity. The mutation therefore affects a component of the asparagine utilization system other than the catabolism of asparagine within the cell; it probably affects asparagine uptake.
\end{abstract}

\section{INTRODUCTION}

Escherichia coli can use L-asparagine as a sole nitrogen source by utilizing an enzyme, Lasparaginase (EC 3.5.1.1), that catalyses the hydrolysis of L-asparagine to L-aspartic acid and ammonia. $E$. coli produces two such enzymes: the first, cytoplasmic L-asparaginase $\mathrm{I}\left(K_{\mathrm{m}}=3.5\right.$ $\mathrm{mM}$ ), is produced constitutively, and is the enzyme responsible for the ability of the cell to use asparagine as a nitrogen source; the second, periplasmic L-asparaginase II $\left(K_{\mathrm{m}}=10 \mu \mathrm{M}\right)$, is produced mainly during anaerobiosis in the presence of high levels of amino acids and is subject to catabolite repression (Schwartz et al., 1966; Campbell et al., 1967; Cedar \& Schwartz, 1967, 1968; Willis \& Woolfolk, 1974; Chesney, 1983). No data exist as to the ability of this latter enzyme to support the growth of $E$. coli with asparagine as a sole nitrogen source due to the fact that the enzyme is not produced when the cells are grown in minimal medium containing only a carbon source and asparagine.

We recently reported the isolation of a mutant $E$. coli strain defective in the production of Lasparaginase I (Del Casale et al., 1983). Strains containing this mutation (ansA) produce no Lasparaginase activity when grown under conditions non-permissive for L-asparaginase II production, and thus cannot utilize asparagine as a sole nitrogen source. It is not yet known whether ans $A$ represents the structural gene or a control element for $L$-asparaginase $I$. In order to analyse the genetic system that allows $E$. coli to utilize L-asparagine, we undertook the isolation of temperature-sensitive mutants unable to grow on asparagine as a sole nitrogen source. We report here on the isolation, mapping and initial characterization of one such mutant, asu, that affects neither the activity nor production of L-asparaginase I and which therefore represents a new genetic component of the asparagine utilization system.

Abbreviation: NNG, $N$-methyl- $N^{\prime}$-nitro- $N$-nitrosoguanidine. 


\section{METHODS}

Bacterial strains. The $E$. coli strains used are listed in Table 1.

Media. Luria broth (LB), tryptone agar, O minimal (OM) agar, OM liquid medium, saline diluent and sodium borate buffer have been previously described (Scott, 1974; Chesney \& Scott, 1978; Chesney \& Adler, 1982; Del Casale et al., 1983). L-Asparagine and sodium aspartate, when used as sole nitrogen sources, were added to a concentration of $5 \mathrm{~mm}$. Thiamine $/ \mathrm{HCl}\left(2 \mu \mathrm{g} \mathrm{ml} \mathrm{m}^{-1}\right)$ was added to all minimal media; other supplement concentrations are as noted in the text. L-Asparagine, sodium aspartate, $N$-methyl- $N^{\prime}$-nitro- $N$-nitrosoguanidine (NNG), sodium penicillin $\mathrm{G}$, kanamycin sulphate, chloramphenicol and tetracycline/HCl were obtained from Sigma.

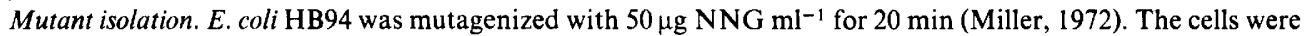
then subjected to two rounds of penicillin enrichment as follows. The mutagenized cells were grown overnight at $30{ }^{\circ} \mathrm{C}$ in $\mathrm{OM}$ liquid medium supplemented with $0.4 \%$ glucose and $5 \mathrm{mM}$-L-asparagine. This was used to start a culture growing in the same medium at $30^{\circ} \mathrm{C}$. At a density of approximately $1 \times 10^{8} \mathrm{cells} \mathrm{ml}^{-1}$, the culture was shifted to $42{ }^{\circ} \mathrm{C}$ and, after a fourfold mass increase, sodium penicillin was added to $10000 \mathrm{U} \mathrm{ml}^{-1}$. After lysis the cells were washed, resuspended in the same medium and grown overnight at $30^{\circ} \mathrm{C}$. The entire process was then repeated. The cells were plated on OM agar containing $0.4 \%$ glucose and $5 \mathrm{mM}$-L-asparagine, incubated for $2 \mathrm{~d}$ at $30^{\circ} \mathrm{C}$ and then replica-plated to the same medium at $42^{\circ} \mathrm{C}$. Methionine $\left(20 \mu \mathrm{g} \mathrm{ml}^{-1}\right)$ was added to all minimal media during enrichment and screening in order to increase growth efficiency since methionine synthesis in $E$. coli is somewhat temperature-sensitive (Ron \& Davis, 1971; Ron \& Shani, 1971).

Growth rate determination. Cultures grown overnight at $34{ }^{\circ} \mathrm{C}$ in $\mathrm{OM}$ liquid medium containing either $\mathrm{L}-$ asparagine or sodium aspartate as the nitrogen source were diluted into the same medium, grown to exponential phase and divided four ways for growth at $34^{\circ} \mathrm{C}$ or $41{ }^{\circ} \mathrm{C}$, with or without methionine. Growth was monitored at $550 \mathrm{~nm}$ using a Gilford model 240 spectrophotometer (Gilford Instrument Laboratories, Orberlin, Ohio, USA); doubling times were determined from the exponential portions of the growth curves.

$F^{\prime}$ mapping. E. coli strain DV942 (asu) was mated with each of $19 \mathrm{~F}^{\prime}$ strains whose $\mathrm{F}^{\prime}$ plasmids together cover the entire genome of $E$. coli [obtained from the $E$. coli Genetic Stock Center (CGSC), Yale University, New Haven, Con., USA]. $\mathrm{F}^{\prime}$ donor strains were grown overnight at $37^{\circ} \mathrm{C}$ without shaking in minimal medium selective for plasmid maintenance. These were diluted fourfold into LB and grown without shaking at $37^{\circ} \mathrm{C}$ for $1 \mathrm{~h}$. A sample $(1 \mathrm{ml})$ of each donor was mixed with an equal volume of exponential phase DV942 $\left(2 \times 10^{8} \mathrm{cells} \mathrm{ml}^{-1}\right.$, grown with

Table 1. Bacterial strains

\begin{tabular}{|c|c|c|c|}
\hline Strain & Relevant genotype & Source & Reference \\
\hline НB94 & hsdR4 thi-1 relAl gal55 & CGSC $^{*}$ & Boyer \& Roulland-Dussoix (1969) \\
\hline DV941 & $a s u$ & NNG mutant of HB94 & This paper \\
\hline DV942 & asu rpsL & $\operatorname{Str}^{r}$ transductant of DV941 & This paper \\
\hline JE5550 & (F506) recAl argE3 rpsL700 & CGSC & Movva et al. (1978) \\
\hline TD202 & $\operatorname{man} A 4$ & $\begin{array}{l}\text { Successive } \mathrm{arg}^{+} \mathrm{aro}^{+} \\
\text {transductant of GMS343† } \\
\text { (from CGSC) }\end{array}$ & Del Casale et al. (1983) \\
\hline TD203 & aroD6 & $\begin{array}{l}\text { Successive } \arg ^{+} \text {manA } \\
\text { transductant of GMS343† } \\
\text { (from CGSC) }\end{array}$ & This paper \\
\hline AG 1025 & $\operatorname{mar} A:: \operatorname{Tn} 5\left(\mathrm{Km}^{\mathrm{r}}\right)$ & S. Levy* & George \& Levy (1983) \\
\hline PLK 1241 & $z d d-230:: \operatorname{Tn} 9\left(\mathrm{Cm}^{\mathrm{r}}\right)$ & S. Levy & Bitner \& Kuempel (1981) \\
\hline PLK 1269 & $\begin{aligned} & z d c-235:: \operatorname{Tn} 10\left(\mathrm{Tc}^{r}\right) \\
& z d d-230:: \operatorname{Tn} 9\end{aligned}$ & CGSC & Bitner \& Kuempel (1981) \\
\hline DV945 & $a s u^{+} z d c-235:: \operatorname{Tn} 10$ & $\begin{array}{l}\text { Transductant of DV942 from } \\
\text { PLK } 1269\end{array}$ & This paper \\
\hline DV946 & asu zdd-230: :Tn9 & $\begin{array}{l}\text { Transductant of DV942 from } \\
\text { PLK } 1269\end{array}$ & This paper \\
\hline DV947 & asu $z d c-235:: \operatorname{Tn} 10$ & $\begin{array}{l}\text { Transductant of DV942 from } \\
\text { PLK } 1269\end{array}$ & This paper \\
\hline $\mathrm{RC} 1102$ & $a s u^{+}$ & $\begin{array}{l}\text { Successive leu } u^{+} \text {dnaG }^{+} \\
\text {transductant of QQ29 } \\
\text { (from N. Sternberg)* }\end{array}$ & This paper \\
\hline $\mathrm{RC} 1103$ & $a s u=d c \cdot 235:: \operatorname{Tn} 10$ & $\begin{array}{l}\text { Transductant of RC1102 } \\
\text { from DV } 947\end{array}$ & This paper \\
\hline
\end{tabular}


shaking at $37^{\circ} \mathrm{C}$ in LB) in a test tube, and the mixtures were incubated for $1 \mathrm{~h}$ without shaking at $34^{\circ} \mathrm{C}$. The cells were then centrifuged, washed twice with saline and plated at several dilutions on OM agar selective for $a s u^{+}$(see below) and counterselective for each $\mathrm{F}^{\prime}$ strain. Plates were incubated at $42^{\circ} \mathrm{C}$ for $2 \mathrm{~d}$ before they were scored for the appearance of $a s u^{+}$colonies.

Transductional analysis. Transductions were performed with P1 vir as previously described (Chesney \& Scott, 1978; Del Casale et al., 1983). Drug resistance markers were selected on tryptone plates containing the appropriate antibiotic $\left(20 \mu \mathrm{g} \mathrm{ml}^{-1}\right)$. Plating of drug resistant transductants was delayed for $2 \mathrm{~h}$ after transduction in order to allow expression of the resistance gene. man $^{+}$transductants were selected on OM plates containing $0.4 \%$ mannose as the sole carbon source. aro $D^{+}$transductants were selected on $\mathrm{OM}$ which lacked aromatic amino acids. Cotransduction of $a s u$ was scored by replica plating to OM containing $0.4 \%$ glucose, $5 \mathrm{~mm}$-asparagine and $20 \mu \mathrm{g}$ methionine $\mathrm{ml}^{-1}$, followed by overnight incubation at $42^{\circ} \mathrm{C}$.

Determination of L-asparaginase activity. Cells grown aerobically in OM liquid medium containing $0.4 \%$ glucose and the appropriate nitrogen source were centrifuged, washed twice in saline, frozen, thawed, resuspended in $0.1 \mathrm{M}$-sodium borate buffer and sonicated at $40 \mathrm{~W}$ on ice for a total of $80 \mathrm{~s}(4 \times 20 \mathrm{~s}$ bursts $)$ using a Branson Model W185 Sonifier (Branson Sonic Power, Danbury, Conn., USA) with a microtip. L-Asparaginase activity in the cleared sonic lysates was determined with Nessler's reagent as previously described (Kafkewitz \& Goodman, 1974).

\section{RESULTS AND DISCUSSION}

\section{Isolation of asu}

E. coli $\mathrm{HB} 94$ was mutagenized with NNG $\left(50 \mu \mathrm{g} \mathrm{ml}^{-1}\right)$ and penicillin enrichment was carried out in such a way as to select for temperature-sensitive growth in medium containing Lasparagine as the sole nitrogen source (see Methods). This was done in order to allow for the possible isolation of a temperature-sensitive ans $A$ mutant, since such a mutant would allow us to demonstrate whether or not ans $A$ represents the structural gene for $\mathrm{L}$-asparaginase I. No ans $A$ mutant was found, but one mutant (DV941) was isolated which had the desired phenotype; while the parent strain grew well at all temperatures regardless of whether the nitrogen source was ammonia, aspartate or asparagine, DV941 was temperature-sensitive for growth on asparagine. Its temperature-sensitivity was exacerbated when methionine was added to the asparagine agar: with methionine absent, growth of DV941 at $42{ }^{\circ} \mathrm{C}$ on asparagine was weak but present; when methionine was added, no growth occured. This effect was manifested by methionine concentrations ranging from 1 to $100 \mu \mathrm{g} \mathrm{ml}^{-1}$. Methionine did not affect the growth of DV941 on either ammonia or aspartate at $42^{\circ} \mathrm{C}$.

In order to assess more accurately the effects of temperature and methionine on the ability of DV941 to utilize asparagine, the doubling times of HB94 and DV941 were determined under various conditions in liquid OM medium (Table 2). Two conclusions may be drawn from these data. (1) The temperature-sensitivity of DV941 was greatly exacerbated by the presence of methionine; at $41{ }^{\circ} \mathrm{C}$ in the absence of methionine the mutant strain grew about as well as its

\section{Table 2. Doubling times of HB94 and DV94I in liquid medium}

Growth curves were determined in OM liquid medium containing $0.4 \%$ glucose with either $5 \mathrm{mM}$ sodium aspartate (Asp) or $5 \mathrm{mM}$-asparagine (Asn). Methionine (Met), when present, was added to a concentration of $40 \mu \mathrm{g} \mathrm{ml}^{-1}$. Cell density was measured at $\mathrm{OD}_{550}$. All growth curves were run at least twice. The doubling times given are from representative experiments, except for the critical results (marked with asterisks and mentioned in the text), for which the experiments were run three times and the times given represent the means of the two best curves.

\begin{tabular}{clcc}
\multirow{2}{*}{ Strain } & Supplements & $\overbrace{34^{\circ} \mathrm{C}}^{\text {Doubling times (min) }}$ \\
HB94 & Asp & 133 & $41^{\circ} \mathrm{C}$ \\
& Asp + Met & 144 & 112 \\
& Asn & $336^{*}$ & 82 \\
DV941 & Asn + Met & $317^{*}$ & 197 \\
& Asp & 160 & 150 \\
& Asp + Met & 114 & 105 \\
& Asn & $77^{*}$ & $170^{*}$ \\
& Asn + Met & $85^{*}$ & No growth*
\end{tabular}




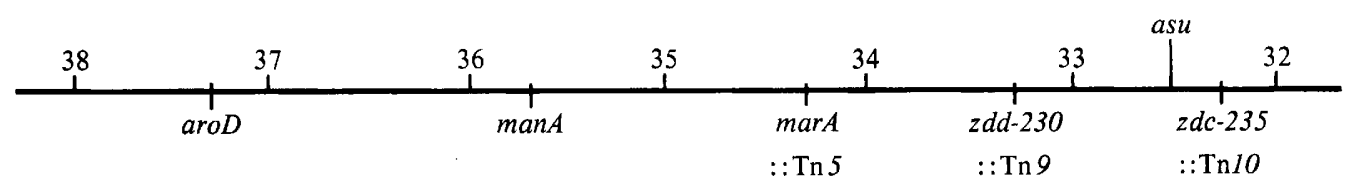

Fig. 1. Escherichia coli chromosomal region covered by F506, showing the positions of markers used in this paper (Movva et al., 1978; Bitner \& Kuempel, 1981; Bachmann, 1983; George \& Levy, 1983) and the position determined for asu.

Table 3. Cotransduction of asu

\begin{tabular}{|c|c|c|c|c|}
\hline $\begin{array}{l}\text { Donor } \\
\text { strain }\end{array}$ & $\begin{array}{l}\text { Recipient } \\
\text { strain }\end{array}$ & Selected marker & $\begin{array}{l}\text { Unselected } \\
\text { marker(s) }\end{array}$ & $\begin{array}{c}\text { Percentage } \\
\text { cotransduction* }\end{array}$ \\
\hline DV941 & TD203 & $\operatorname{aro} D^{+}$ & asu & $<0.5$ \\
\hline DV941 & TD202 & $\operatorname{man} A^{+}$ & asu & $<0.3$ \\
\hline AG1025 & DV942 & $\operatorname{mar} A:: \operatorname{Tn} 5\left(\mathrm{Km}^{r}\right)$ & $a s u^{+}$ & 0.93 \\
\hline PLK1241 & DV942 & $z d d-230\left(\mathrm{Cm}^{\mathrm{r}}\right)$ & $a s u^{+}$ & $14 \cdot 1$ \\
\hline PLK 1269 & DV942 & $z d c-235\left(\mathrm{Tc}^{\mathrm{r}}\right)$ & $a s u^{+}$ & $85 \cdot 8$ \\
\hline \multirow[t]{2}{*}{ DV945 } & DV946 & $z d c-235\left(\mathrm{Tc}^{\mathrm{r}}\right)$ & $\mathrm{Cm}^{\mathrm{s}}$ & $18 \cdot 0$ \\
\hline & & & $a s u^{+}$ & $85 \cdot 0$ \\
\hline \multirow{4}{*}{ PLK 1241} & $\mathrm{RCl103}$ & $z d d-230\left(\mathrm{Cm}^{\mathrm{r}}\right)$ & $a s u^{+} \mathrm{Tc}^{\mathrm{s}}$ & 6.8 \\
\hline & & & $a s u^{+} z d c-235\left(\mathrm{Tc}^{r}\right)$ & $3 \cdot 4$ \\
\hline & & & $\operatorname{asu} \mathrm{Tc}^{\mathrm{s}}$ & $<1.0$ \\
\hline & & & asu $z d c-235\left(\mathrm{Tc}^{\mathrm{r}}\right)$ & $89 \cdot 8$ \\
\hline
\end{tabular}

* At least 100 transductants were scored in each experiment.

parent (Table 2). Growth of DV941 at $41{ }^{\circ} \mathrm{C}$ in the presence of methionine did not cease immediately upon shift-up, but continued for at least two doublings (data not shown). Furthermore, the defect was reversible; growth could resume after a shift-down to the permissive temperature following overnight shaking at $41{ }^{\circ} \mathrm{C}$. (2) DV941 grew three to four times faster in asparagine at $34^{\circ} \mathrm{C}$ than the parent strain (Table 2). The presence or absence of methionine at this temperature had no effect. The mutation thus appears to enhance the utilization of asparagine at the permissive temperature. This was confirmed with another pair of strains, RC1102 and RC1103 (asu) (data not shown).

To determine whether any other amino acids exerted the same effect as methionine, several others were tested for their effect on the ability of DV941 to grow on OM asparagine plates at $42{ }^{\circ} \mathrm{C}$. Of those tested only alanine had the same effect as methionine. This is a somewhat surprising finding considering that methionine $\left(\mathrm{R}=\mathrm{CH}_{2}-\mathrm{CH}_{2}-\mathrm{S}-\mathrm{CH}_{3}\right)$ and alanine $\left(\mathrm{R}=\mathrm{CH}_{3}\right)$ are structurally quite dissimilar and have no known interconversion pathway (Umbarger, 1978).

Because of the similarity of glutamine to asparagine, we tested DV 941 for its ability to utilize $5 \mathrm{~mm}$-glutamine as a sole nitrogen source. No differences in glutamine utilization were observed between DV941 and HB94 with regard to temperature or methionine sensitivity. The mutation was therefore dubbed asu since only asparagine $u$ tilization was affected.

\section{Mapping of asu}

Conjugational analysis. A set of $19 \mathrm{~F}^{\prime}$ strains whose plasmids cover the entire chromosome of E. coli were mated with DV942 (asu Strr), as described in Methods, in order to determine the general location of the mutation. One donor strain, JE5550, which carries F506, complemented $a s u$, indicating that the mutation is located within the region covered by F506, which is approximately 32 to $38 \mathrm{~min}$ on the $E$. coli map. The mutation $a s u$ does not, therefore, represent the same gene as ans $A$, which maps at $39 \mathrm{~min}$ (Del Casale et al., 1983) and which is not complemented by F506.

Transductional analysis. To determine the position of asu more accurately we measured its cotransduction frequencies with other markers within the region indicated by the $F^{\prime}$ analysis. Genetic markers located in the region covered by F506 are shown in Fig. 1. Since this region of the map contains relatively few established markers, being within a 'cotransduction gap' (Bachmann, 1983), we made use of several transposon insertions that had been mapped in the 
Table 4. L-Asparaginase I activity at 30 and $42^{\circ} \mathrm{C}$

Cells were grown at $34{ }^{\circ} \mathrm{C}$ in $\mathrm{OM}+0.4 \%$ glucose $+0.1 \%\left(\mathrm{NH}_{4}\right)_{2} \mathrm{SO}_{4}$. Methionine (Met), when present, was added to the assay tubes at a concentration of $20 \mu \mathrm{g} \mathrm{ml}^{-1}$. Values are means of two determinations.

$\begin{array}{ccc}\text { Strain } & \text { Assay conditions } & \begin{array}{c}\text { L-Asparaginase I } \\ \text { activity }\end{array} \\ \text { HB94 } & 30^{\circ} \mathrm{C} & \text { [IU (mg protein })^{-1} \text { ] } \\ & 42^{\circ} \mathrm{C} & 0.046 \\ \text { DV941 } & 42^{\circ} \mathrm{C}+\text { Met } & 0.096 \\ & 30^{\circ} \mathrm{C} & 0 \cdot 108 \\ & 42^{\circ} \mathrm{C} & 0.061 \\ & 42{ }^{\circ} \mathrm{C}+\text { Met } & 0 \cdot 108 \\ & & 0.095\end{array}$

area (Bitner \& Kuempel, 1981; George \& Levy, 1983). The cotransduction data (Table 3), especially the three-point cross between PLK1241 (zdd-230::Tn9) and RC1103 (asu zdc$235:: \operatorname{Tn} 10)$, indicate that asu maps between $z d d-230:: \operatorname{Tn} 9\left(\mathrm{Cm}^{\mathrm{r}}\right)$ and $z d c-235:: \operatorname{Tn} 10\left(\mathrm{Tet}^{\mathrm{r}}\right)$ and that $a s u$ and $z d c-235$, which cotransduce at approximately $85 \%$, are 0.1 to $0.2 \mathrm{~min}$ apart (Wu, 1966). The mutation $a s u$, therefore, maps at $32.4 \mathrm{~min}$ on the E. coli map (Fig. 1). It thus represents a new locus in the 'cotransduction gap', one of several to be mapped into this area recently (Skinner \& Cooper, 1982; George \& Levy, 1983).

We have determined the reversion frequency of asu to temperature resistance to be $4 \times 10^{-7}$, suggesting that this trait is due to a single point mutation. Analysis of a number of these revertants, unfortunately, yielded a variety of phenotypes (some equivalent to the wild-type) with respect to growth at low temperature, suggesting the presence of a number of pseudorevertants. This made it difficult to ascertain whether both the high and low temperature phenotypes expressed by asu strains were due to a single mutation. We therefore attempted to determine whether the two phenotypes could be separated via transduction: DV942 asu was transduced to tetracycline resistance from DV945 $\left(z d c-235 a s u^{+}\right)$and the transductants were screened for temperature sensitivity or resistance and for growth at $30^{\circ} \mathrm{C}$ on asparagine plates containing methionine. In all, 132 colonies were screened. The results showed that all colonies (113) that had been cotransduced to temperature-resistance $\left(a s u^{+}\right)$had concomitantly lost the ability to grow rapidly on asparagine at low temperature, while all colonies (19) that had retained the temperature-sensitive (asu) allele had also retained this ability. This failure to detect segregation $(<0.8 \%)$ of the two phenotypes strongly suggests that both result from a single mutation, although we cannot completely exclude the possibility that they result from two closely linked mutations.

\section{L-Asparaginase I production by DV941 asu}

To determine whether asu affected the activity of L-asparaginase I, HB94 and DV941 were grown to stationary phase at $34{ }^{\circ} \mathrm{C}$ in $\mathrm{OM}$ liquid containing $0.4 \%$ glucose and $0 \cdot 1 \%\left(\mathrm{NH}_{4}\right)_{2} \mathrm{SO}_{4}$ (conditions that are non-permissive for the production of L-asparaginase II), and cleared sonic lysates were prepared. These lysates were then assayed at $30^{\circ} \mathrm{C}, 42{ }^{\circ} \mathrm{C}$ and at $42{ }^{\circ} \mathrm{C}$ in the presence of methionine. The enzyme activities obtained from both HB94 and DV941 increased significantly with the increase in temperature, and the addition of methionine had at most a minimal effect on activity (Table 4). We therefore concluded that since DV941 does not produce a temperature-sensitive L-asparaginase I, asu does not represent the structural gene for this enzyme.

To determine whether asu affected the production of L-asparaginase I rather than the enzyme itself, HB94 and DV941 were grown under a variety of conditions, all non-permissive for Lasparaginase II production, in order to test for the effects of both temperature and methionine on enzyme production. The two strains yielded similar patterns of enzyme activity in response to growth conditions, indicating that enzyme production was not affected by the mutation (Table 5). The experiments were repeated with asparagine as the nitrogen source (as opposed to ammonia, which was used in the experiments shown in Table 5) to eliminate the possibility that 
Table 5. L-Asparaginase I activity in cultures grown under various conditions

Cells were grown overnight at either 34 or $41{ }^{\circ} \mathrm{C}$ in $\mathrm{OM}+0.4 \%$ glucose and $0.1 \%\left(\mathrm{NH}_{4}\right)_{2} \mathrm{SO}_{4}$, with or without $40 \mu \mathrm{g}$ methionine $\mathrm{ml}^{-1}$. Asparaginase assays were done at $37^{\circ} \mathrm{C}$. Values are means of two determinations.

$\begin{array}{ccc}\text { Strain } & \text { Growth conditions } & \begin{array}{c}\text { L-Asparaginase I } \\ \text { activity }\end{array} \\ \text { HB94 } & 34^{\circ} \mathrm{C} & 0 \cdot 056 \\ & 34^{\circ} \mathrm{C}+\text { Met } & 0 \cdot 076 \\ & 41^{\circ} \mathrm{C} & 0 \cdot 024 \\ \text { DV941 } & 41^{\circ} \mathrm{C}+\text { Met } & 0 \cdot 036 \\ & 34^{\circ} \mathrm{C} & 0 \cdot 031 \\ & 34^{\circ} \mathrm{C}+\text { Met } & 0 \cdot 081 \\ & 41^{\circ} \mathrm{C} & 0 \cdot 026 \\ & 41^{\circ} \mathrm{C}+\text { Met } & 0 \cdot 046\end{array}$

asu affects enzyme levels under these conditions. (Since DV941 stops growing at $41^{\circ} \mathrm{C}$ in the presence of methionine, all cultures were harvested about $1 \mathrm{~h}$ after the growth of DV941 had ceased.) The results under these conditions were as before: HB94 and DV941 yielded similar amounts of enzyme activity (data not shown). The mutation therefore affects neither the thermo-stability of L-asparaginase I nor its production, indicating that asu represents a new genetic component of the asparagine utilization system.

Preliminary evidence suggests that asu may represent a mutation in the asparagine uptake system. The nature of this evidence is as follows. E. coli has been previously determined to have a two-component asparagine uptake system: a high-efficiency component $\left(K_{\mathrm{m}}=3.5 \mu \mathrm{M}\right)$ and a low-efficiency component $\left(K_{\mathrm{m}}=>80 \mu \mathrm{M}\right)$. The former component was found to be either repressed or inactivated at asparagine concentrations greater than $1 \mathrm{mM}$ and it was therefore concluded that the low-efficiency system alone allows the utilization of $5 \mathrm{~mm}$-asparagine as a nitrogen source (Willis \& Woolfolk, 1975). If asu represents a transport mutation, it should lie in the low-efficiency component since it affects asparagine utilization at a concentration of $5 \mathrm{~mm}$. We therefore decided to test DV941 for the ability to utilize asparagine under conditions in which the high-efficiency uptake component should be active. HB94 and DV941 were plated on OM plates containing methionine and either $5 \mathrm{~mm}$ or $0.75 \mathrm{~mm}$-asparagine and the plates were incubated at either $30^{\circ} \mathrm{C}$ or $42^{\circ} \mathrm{C}$. HB94, as expected, grew on the $5 \mathrm{~mm}$-asparagine at both temperatures; on $0.75 \mathrm{~mm}$-asparagine it grew weakly (since much less nitrogen was available) but, again, equally well at both temperatures. DV941, also as expected, grew on the $5 \mathrm{mM}$ asparagine only at $30^{\circ} \mathrm{C}$. However, on the $0.75 \mathrm{~mm}$-asparagine it grew as well at both temperatures as HB94, suggesting the possibility that activation of the high-efficiency asparagine uptake component allowed the $\mathrm{Asu}^{-}$strain to utilize the available asparagine at high temperature in the presence of methionine. Asparagine uptake experiments are being planned to test this possibility and to determine the nature of the methionine effect.

We do not as yet know why the isolation of temperature-sensitive ans $A$ mutants has proven so refractory; neither this study nor an analysis of $\mathrm{Ans}^{+}$revertants from the original ans $A$ strains has produced any. One possible explanation for this failure may simply be that ans $A$ represents not the structural gene for L-asparaginase I but a gene controlling its synthesis. If this is true, however, one must then wonder why extensive screening failed to yield any mutants in the structural gene. Interestingly, a study involving the isolation of Saccharomyces cerevisiae Lasparaginase II mutants similarly failed to yield temperature-sensitive mutants despite intensive efforts (Kim \& Roon, 1984). Whether this might have significance with regard to the structure of L-asparaginases in general, or whether it is merely coincidence, cannot yet be determined.

We thank S. Levy, N. Sternberg and B. Bachmann for the generous gifts of strains used in this work. We also thank D. Kafkewitz and E. Kirby for many helpful discussions.

This work was supported by Public Health Service Biomedical Research Support Grant RR-7059 from the National Institutes of Health and by a grant from the Rutgers Research Council. 


\section{REFERENCES}

BaChManN, B. J. (1983). Linkage map of Escherichia coli K-12. Edition 7. Microbiological Reviews 47, 180230.

Bitner, R. M \& Kuempel, P. L. (1981). Pl transduction map spanning the replication terminus of Escherichia coli K-12. Molecular and General Genetics 184, 208-212.

Boyer, H. W. \& Roulland-Dussoix, D. (1969). A complementation analysis of the restriction and modification of DNA in Escherichia coli. Journal of Molecular Biology 41, 459-472.

Campbell, H. A., Mashburn, L. T., Boyse, E. A. \& OLD, L. J. (1967). Two asparaginases from Escherichia coli B. Their separation, purification and antitumor activity. Biochemistry 6, 721-730.

Cedar, H. \& Schwartz, J. H. (1967). Localization of the two L-asparaginases in anaerobically grown Escherichia coli. Journal of Biological Chemistry 242, 3753-3754.

Cedar, H. \& Schwartz, J. H. (1968). Production of Lasparaginase II by Escherichia coli. Journal of Bacteriology 96, 2043-2048.

ChesNey, R. H. (1983). E. coli L-asparaginase II production in the presence and absence of catabolite activating protein. FEMS Microbiology Letters 17, 161-162.

CHesney, R. H. \& ADLER, E. (1982). Chromosomal location of attP7, the $\operatorname{rec} A$-independent $\mathrm{P} 7$ integration site used in the suppression of Escherichia coli dnaA mutations. Journal of Bacteriology 150, 14001404.

Chesney, R. H. \& ScotT, J. R. (1978). Suppression of a thermosensitive dnaA mutation of Escherichia coli by bacteriophage P1 and P7. Plasmid 1, 145-163.

Del Casale, T., Sollitti, P. \& Chesney, R. H. (1983). Cytoplasmic L-asparaginase: isolation of a defective strain and mapping of ansA. Journal of Bacteriology 154, 513-515.

GeORGE, A. M. \& LeVY, S. B. (1983). Gene in the major cotransduction gap of the Escherichia coli K-12 linkage map required for the expression of chromosomal resistance to tetracycline and other antibiotics. Journal of Bacteriology 155, 541-548.

KafKewitz, D. \& Goodman, D. (1974). L-Asparagin- ase production by the rumen anaerobe Vibrio succinogenes. Applied Microbiology 27, 206-209.

KIM, K. W. \& Roon, R. J. (1984). Asparaginase II of Saccharomyces cerevisiae: positive selection of two mutations that prevent enzyme synthesis. Journal of Bacteriology 157, 958-961.

MilleR, J. H. (1972). Experiments in Molecular Genetics. Cold Spring Harbor, NY: Cold Spring Harbor Laboratory.

Movva, N. R., Katz, E., Asdourian, P. L., Hirota, Y. \& INOUYE, M. (1978). Gene dosage effects of the structural gene for a lipoprotein of the Escherichia coli outer membrane. Journal of Bacteriology 133, 8184.

Ron, E. Z. \& Davis, B. D. (1971). Growth rate of Escherichia coli at elevated temperatures: limitation by methionine. Journal of Bacteriology 107, 391-396.

RoN, E. Z. \& SHANI, M. (1971). Growth rate of Escherichia coli at elevated temperatures: reversible inhibition of homoserine trans-succinylase. Journal of Bacteriology 107, 397-400.

SchwartZ, J. H., Reeves, J. Y. \& Broome, J. D. (1966). Two L-asparaginases from $E$. coli and their action against tumors. Proceedings of the National Academy of Sciences of the United States of America 56, 1516-1519.

ScotT, J. R. (1974). A turbid plaque-forming mutant of phage P1 that cannot lysogenize Escherichia coli. Virology 62, 344-349.

SKINNER, M. A. \& COOPER, R. A. (1982). An Escherichia coli mutant defective in the NADdependent succinate semialdehyde dehydrogenase. Archives of Microbiology 132, 270-275.

UMBARGER, H. E. (1978). Amino acid biosynthesis and its regulation. Annual Review of Biochemistry 47, 533606.

Willis, R. C. \& Woolfolk, C. A. (1974). Asparagine utilization in Escherichia coli. Journal of Bacteriology 118, 231-241.

Willis, R. C. \& Woolfolk, C. A. (1975). LAsparagine uptake in Escherichia coli. Journal of Bacteriology 123, 937-945.

WU, T. T. (1966). A model for three-point analysis of random general transduction. Genetics 54, 405-410. 